DOI: $10.47743 /$ jss-2021-67-4-19

\title{
Suveranitatea digitală - viitorul spaţiului virtual?
}

\section{Is Cybersovereignty the Future of Cyberspace?}

\section{Carmen Moldovan ${ }^{1}$}

Rezumat: Conceptul de suveranitate digitală a fost promovat intens de către China şi Federaţia Rusă şi se doreşte a fi o transpunere în mediul virtual a principiului suveranităţii din dreptul internaţional public. De esenţa sa este opoziţia faţă de ideea libertăţii internetului în lipsa reglementărilor din partea statelor. Prezenta lucrare îşi propune să exploreze, dintr-o perspectivă critică, principalele trăsături şi implicaţii ale suveranităţii digitale, prin trimitere la principiile dreptului internaţional. Până în prezent, la nivelul ONU s-a cristalizat concluzia aplicabilităţii principiilor dreptului internaţional în Cyberspace (inclusiv a principiului suveranităţii), însă nu este clar dacă aplicarea acestora se realizează în aceeaşi parametri şi având acelaşi sens ca în spaţiul fizic.

Cuvinte-cheie: principii; ONU; reglementare; suveranitate; aplicare teritorială

Abstract: Cybersovereignty is a concept highly supported by China and the Russian Federation, considering it as an application of the principle of state sovereignty. In essence, it is opposed to the idea of an open Internet outside State regulations. The aim of this paper is to critically explore the main features and implications of the concept of Cybersovereignty by reference to the basic principle of sovereignty in International Law. At this date, within the United Nations the conclusion of specialized working groups is that principles and norms of International Law are applicable in Cyberspace. However, it is far from clear if the same parameters and meaning as in the physical space are applicable.

Keywords: principles; UN; regulation; sovereignty; territorial application

\section{Introducere}

Dezvoltarea internetului a avut un efect omniprezent asupra comunicaţiilor şi tehnologiei, afectând şi dezvoltând multe niveluri de activitate umană şi creând spaţiul cibernetic ca mediu global care nu poate exista în absenţa lui.

Statele şi dreptul internaţional nu au putut să se adapteze cu uşurinţă la evoluţia dinamică a tehnologiei şi să reacţioneze prin reglementarea tuturor problemelor legate de utilizarea şi mijloacele de comunicare ale acesteia. În acest sens, reacţia companiilor private, direct implicate şi interesate de acest domeniu şi adesea în afara contribuţiei şi sprijinului statelor a fost mai promptă în aşa fel încât

\footnotetext{
${ }^{1}$ Lector univ. dr., Facultatea de Drept, Universitatea „Alexandru Ioan Cuza” din Iaşi, email: carmen.moldovan@uaic.ro
} 
paradigma normativă în reglementarea acestui mediu a trecut de la controlul exclusiv al statelor pentru a deveni un interesul mai multor părţi interesate.

Totuşi, scopul de a asigura aplicarea efectivă a normelor de drept internaţional în spaţiul cibernetic şi, în acelaşi timp, securitatea utilizatorilor acestuia se poate dovedi necesar în anumite contexte, dar nu poate justifica mijloace autoritare.

Prezenta lucrare îşi propune să analizeze dintr-o perspectivă critică, teoretică şi practică, ideea de suveranitate cibernetică (cybersovereignty). Spre deosebire de alte domenii ale dreptului internaţional, operaţiunile cibernetice reprezintă o formă relativ nouă de relaţii ale statelor, iar spaţiul cibernetic este considerat o zonă "gri” a dreptului internaţional, aparent în mare măsură neexploatată de state, din care dreptul internaţional nu poate fi exclus, însă se impune luarea în considerare a regulilor şi principiilor acestuia raportat la caracteristicile Cyberspace (denumire ce va fi folosită în cuprinsul prezentei lucrări pentru a desemna spaţiul cibernetic).

Evoluţiile recente de la nivelul Naţiunilor Unite constând în raporturile grupurilor de lucru special create - UN Group of Experts şi UN Open-ended Working Group - pe tema aplicării dreptului internaţional în Cyberspace au subliniat că dreptul internaţional este aplicabil fără a furniza detalii şi fără a preciza care sunt consecinţele juridice ale acestei constatări. În scopul acestei lucrări, termenul de suveranitate cibernetică se referă la aplicarea principiului suveranităţii statului în spaţiul cibernetic.

Există o asimetrie între crearea şi dinamica constantă a evoluţiei Cyberspace şi dezvoltarea unor reguli specifice drept internaţional în acest domeniu. Lacunele normative pot părea semnificative, iar necesitatea de a le acoperi este una reală şi poate avea consecinţe inclusiv asupra instituţiei răspunderii statului pentru fapte ilicite. Obiectivul prezentei lucrări este de a demonstra că aplicarea sensului teritorial clasic al suveranităţii în Cyberspace este incompatibilă cu trăsăturile spaţiului cibernetic ca mediu global şi cele două concepte pot fi reconciliate doar dacă statele acceptă o interpretare evolutivă a aplicării suveranităţii în acest mediu.

\section{Cybersovereignty - concept şi implicaţii}

Ideea de suveranitate cibernetică ce presupune crearea şi controlul asupra unui „ciberspaţiu naţional”, reglementat de legile interne ale unui stat este o manifestare a autoritarismului ce urmăreşte justificarea preluării controlului deplin asupra acestui mediu şi asupra internetului şi separarea acestora de reţeaua globală, ceea ce este contrar înseşi esenţei lor. $\mathrm{O}$ astfel de abordare este prezentată ca o

${ }^{2}$ M. Mueller, Sovereignty and Cyberspace: Institutions and Internet governance, Essay presented at the 5th Annual Vincent and Elinor Ostrom Memorial Lecture, given at the University of Indiana October 3rd 2018, [Online] la http://dlc.dlib.indiana.edu/dlc/ bitstream/handle/10535/10410/5th-Ostrom-lecture-DLC.pdf?sequence=1\&isAllowed=y, accesat 10.10.2021. 
alternativă la hegemonia Statelor Unite în Cyberspace ca spaţiu global ${ }^{3}$ şi ca mijloc de a asigura principiul egalităţii între state ţinând cont de faptul că există diferenţe semnificative în ceea ce priveşte accesul real la Cyberspace din cauza nivelului tehnologic de dezvoltare inegal, rezultatul fiind un mediu fragmentat.

Această afirmaţie nu poate fi privită ca un argument pertinent având în vedere exact gradul de dezvoltare tehnologică, este puţin probabil ca ţările mai puţin dezvoltate să poată asigura efectiv securitatea reţelei lor cibernetice naţional, invocarea unor astfel de motive subliniază că problema reglementărilor în mediul Cyberspace este un instrument al rivalităţii geopolitice ${ }^{4}$.

Cyberspace este caracterizat uneori ca haotic, anarhic ${ }^{5}$ şi asimetric în raport cu resursele şi capacităţile celor care participă la diferite operaţiuni ${ }^{6}$ pentru a justifica ideea unei suveranităţi cibernetice a statului care îşi protejează interesele în raport cu alte state, însă afirmarea acestui principiu nu rezolvă toate problemele ulterioare: răspunderea statului, consecinţe asupra intereselor şi drepturilor persoanelor private şi a actorilor nestatali.

Oricât de neclară ar fi la acest moment întinderea şi conţinutul principiilor aplicabile în acest mediu, caracterizarea ca anarhică nu este una satisfăcătoare. Caracteristici precum complexitatea, diversitatea utilizatorilor (state, actori nestatali, companii private, persoane private) au determinat crearea mai multor niveluri şi diferite tipuri de relaţii între utilizatorii săi, în funcţie de calitatea acestora şi de natura raporturilor create. Este întemeiată opinia potrivit căreia poate fi, din punct de vedere tehnic şi juridic, secţionat în mai multe părţi: rețele publice accesibile tuturor şi nelimitate de frontiere interne, cu acces liber; rețele teritoriale precum intranet-uri militare sau reţele guvernamentale cu acces limitat; reţele exclusive - pentru servicii de e-guvernare, afaceri, finanţe - accesul este limitat la persoanele autorizate ${ }^{7}$. Conceptul cybersovereignty nu ia în considerare aceste aspecte. Din aceste motive, termenul poate fi considerat inexact sau greşit pentru că principiul suveranităţii, care este piatra de temelie a dreptului internaţional, nu poate fi transferat pe deplin în Cyberspace. Noţiunea de suveranitate teritorială în spaţiul cibernetic trebuie aplicată în mod restrictiv, doar în raport cu elementele infrastructurii IT\&C de pe teritoriul statului. Totodată, interpretarea

${ }^{3}$ Y. Shen, Cyber Sovereignty and the Governance of Global Cyberspace, Chin. Polit. Sci. Rev. (2016) 1:81-93, p. 82.

${ }^{4}$ H. Moynihan, Power Politics Could Impede Progress on Responsible Regulation of Cyberspace, 3 December 2019, [Online] la https:/www.chathamhouse.org/expert/ comment/power-politics-could-impede-progress-responsible-regulation-cyberspace, accesat 20.10.2021.

${ }^{5} \mathrm{~S}$. Arsène, Global Internet Governance in Chinese Academic Literature. Rebalancing a Hegemonic World Order? in China Perspectives 2016/2 | 2016 What Kind of International Order Does China Want, p. 28, https://doi.org/10.4000/chinaperspectives.6973.

${ }^{6}$ Y. Shen, op. cit., p. 84.

${ }^{7}$ J. Zeng, T. Stevens, Y. Chen, China's Solution to Global Cyber Governance: Unpacking the Domestic Discourse of 'Internet Sovereignty', Politics \& Policy, Volume 45, No. 3, 2017, pp. 432-464, 451, https://doi.org/10.1111/polp.12202. 
domeniului de aplicare a acestui principiu ar trebui făcută ţinând cont de evoluţia termenilor şi a relaţiilor reglementate de dreptul internaţional public pentru a acoperi decalajul în reglementarea comportamentului statelor în acest mediu.

\section{Implicaţii ale caracterului sui generis al Cyberspace}

$\mathrm{Nu}$ există consens între state cu privire la reglementarea Cyberspace sau chiar cu privire la înţelegerea funcţionării acestuia în acest mediu complex, a cărui definire şi caracteristici provin din literatura science-fiction, din Neuromantul scris de Wiliam Gibson. Aceste aspecte nu vor fi abordate în cuprinsul prezentei lucrări deoarece au făcut obiectul unor alte studii şi articole ${ }^{8}$. O definiţie standard sau obiectivă a acestui mediu lipseşte ${ }^{9}$ astfel că termenul este utilizat în general în privinţa oricăror aspecte ale utilizării reţelelor de computere şi internet şi pentru a descrie legăturile cu reţelele şi computerele ${ }^{10}$ mai ales în domeniul securităţii ${ }^{11}$. Lipsa unei definiţii unice nu este însă de natură a împiedica aplicarea regulilor şi principiilor dreptului internaţional în acest mediu şi în privinţa conduitei statelor ${ }^{12}$.

Spre deosebire de teritoriul statului, care are o dimensiune fizică şi materială unde este aplicabil principiul suveranităţii, Cyberspace este în întregime creaţia omului $^{13}$ şi constituie o reţea globală complexă, un spaţiu logic, nelimitat, imperceptibil, nematerializat, dependent de timp ${ }^{14}$, în continuă schimbare, un

${ }^{8}$ C. Moldovan, Blurred lines in defining the conduct of States in Cyberspace. A critical analysis on the cyber sovereignty and impact over free access to information, presented at European Society of International Law Kraków-Leiden Online Symposium on 'Exploring the Frontiers of International Law in Cyberspace', 4 December 2020; C. Moldovan, Limits of International Law in a limitless Cyberspace. Challenges and uncertainties, în Analele Știinţifice ale Universităţii „Alexandru Ioan Cuza” din Iași, Tomul LXVI/Supliment, Știinţe juridice, 2020, pp. 315-326, [Online] la http://pub.law.uaic.ro/files/articole/2020/2020_ i_bis/21._moldovan_dip_cyberspace.pdf, accesat 20.10.2021; C. Moldovan, Are there any limits to the rights of States in Cyberspace? An analysis from the perspective of International Law, presented at the 13th Biennial International Conference organised by the Faculty of Law of the West University of Timișoara, 6-7 November 2020.

${ }^{9}$ R. Ottis, P. Lorents, Cyberspace: Definition and Implications, in Proceedings of the 5th International Conference on Information Warfare and Security, Dayton, OH, US, 8-9 April 2010, [Online] la https://ccdcoe.org/library/publications/cyberspace-definition-andimplications/, accesat 20.10.2021.

${ }^{10}$ Ibidem.

${ }^{11}$ E. Donahoe, The Need for a Paradigm Shift on Digital Security, eds. Fen Osler Hampson and Michael Sulmeyer, Getting beyond Norms New Approaches to International Cyber Security Challenges Special Report, Centre for International Governance Innovation, 2017, p. 31

${ }^{12}$ C. Moldovan, op. cit., Limits .... 2020, p. 318-319.

${ }^{13}$ M. Baezner, P. Robin, Trend Analysis: Cyber Sovereignty, Risk and Resilience Team Center for Security Studies (CSS) ETH Zürich, 2018, p. 8.

${ }^{14}$ R. Ottis, P. Lorents, op. cit. 
sistem informaţional interconectat creat de actori nestatali, fără frontiere ${ }^{15}$, ce este legat de teritoriul fizic prin infrastructură fără de care nu poate exista ${ }^{16}$.

Toate aceste elemente descriu un fenomen sui generis ${ }^{17}$, probabil una dintre cele mai mari creaţii ale umanităţii din prezent, un spaţiu civil şi militar deopotrivă ce nu poate fi e supus controlului exclusiv al statelor, deoarece nu poate fi plasat sub suveranitatea statului ${ }^{18}$.

Caracteristicile speciale aseamănă acest mediu cu cele în care statele nu îşi exercită jurisdicţia exclusivă sau se bucură de prerogative speciale, cum ar fi marea liberă sau spaţiul cosmic ce au regim juridic special.

Complexitatea Cyberspace şi trăsăturile sale explică motivele furnizării unei definiţii general acceptate sau incluse în cuprinsul unui tratat internaţional. $\mathrm{O}$ astfel de sarcină se poate dovedi nu doar dificilă, ci şi imposibilă (sens în care amintim lipsa reglementărilor cu caracter obligatoriu în acest domeniu, cu excepţia Convenţiei de la Budapesta privind criminalitatea informatică ${ }^{19}$, adoptată în cadrul Consiliului Europei). În acest context, crearea la nivelul Naţiunilor Unite a grupurilor de lucru specializate - UNGGE (the Group of Governmental Experts on Developments in the Field of Information and Telecommunications in the Context of International Security) şi OEWG (Open-ended working group on developments in the field of information and telecommunications in the context of international security $)^{20}$ - reprezintă o încercare de a clarifica aplicabilitatea regulilor dreptului internaţional public. Începând cu anul $2013^{21}$ până în prezent, concluziilor ambele

${ }^{15}$ K. Nyman Metcalf, Legal View on Outer Space and Cyberspace: Similarities and Differences, Tallinn Paper No. 10, 2018, p. 2, [Online] la https://ccdcoe.org/uploads/ 2018/10/Tallinn-Paper_10_2018.pdf, accesat 12.10.2021.

${ }^{16}$ Y. Shen, op. cit., p. 83.

${ }^{17}$ D. Broeders, L. Adamson, R. Creemers, Coalition of the unwilling? Chinese and Russian perspectives on cyberspace, in The Hague Program For Cyber Norms Policy Brief. November 2019, p. 2, [Online] la https://papers.ssrn.com/sol3/papers.cfm?abstract_id= 3493600, accesat 29.11.2021.

${ }^{18} \mathrm{~W}$. Heintschel von Heinegg, Legal Implications of Territorial Sovereignty in Cyberspace, in 4th International Conference on Cyber Conflict C. Czosseck, R. Ottis, K. Ziolkowski (Eds.), NATO CCDCOE Publications, 2012, p. 8.

${ }^{19}$ Council of Europe, Convention on Cybercrime, 23.XI.2001, ETS No.185.

${ }^{20}$ UNODA, Fact Sheet - Developments in the field of information and telecommunications in the context of International Security, 2019, [Online] la https://unoda-web.s3.amazonaws. com/wp-content/uploads/2019/07/Information-Security-Fact-Sheet-July-2019.pdf, accesat 21.10.2021.

${ }^{21}$ United Nations General Assembly, Group of Governmental Experts on Developments in the Field of Information and Telecommunications in the Context of International Security, para. 19, U.N. Doc. A/68/98, June 24, 2013, [Online] la http://undocs.org/A/68/98, accesat 21.10.2021; United Nations General Assembly, Report of the Group of Governmental Experts on Developments in the Field of Information and Telecommunications in the Context of International Security, A/70/174, 2015, [Online] la https://undocs.org/A/ 70/174, accesat 21.10.2021; United Nations General Assembly (2018), Resolution adopted by the General Assembly on 22 December 2018 on "Advancing responsible State behaviour in Cyberspace in the context of international security", UN Doc A/RES/73/266, [Online] la 
grupuri au fost în sensul aplicării dreptului internaţional pentru conduita statelor în acest mediu, însă un rol esenţial în lămurirea efectelor acestora revine statelor, care au exprimat oficial puncte de vedere fie în cadrul grupurilor de lucru, fie prin declaraţii speciale în această privinţă.

Normele privind comportamentul responsabil al statelor în Cyberspace, identificate prin documentele celor două grupuri de lucru, au fost considerate norme acceptate voluntar de către state (voluntary norms) ${ }^{22}$, exprimare ce este ambiguă şi conturează lipsa forţei juridice obligatorii şi creează incertitudine inclusiv în ceea ce priveşte aplicarea principiului suveranităţii în acest mediu.

Concluzii din luna iulie 2020 ale OEWG subliniază rolul esenţial al Raportului din 2015 adoptat în cadrul UNGGE, care susţine necesitatea implementării normelor voluntare identificate pentru a asigura caracterul public al internetului, prin raportare la obligaţia de respectare a drepturilor fundamentale ${ }^{23}$. Un alt document, din octombrie 2020, denumit The future of discussions on ICTs and Cyberspace at the $U N^{24}$ propune stabilirea unui Program de acţiune pentru promovarea comportamentului responsabil al statului în spaţiul cybernetic (Programme of Action for advancing responsible State behaviour in Cyberspace), în vederea încetării discuţiilor în două niveluri (GGE şi OEWG) şi a stabilirii unui forum permanent în cadrul Naţiunilor Unite pentru analiza utilizării tehnologiilor de informaţii şi comunicare de către state în contextul securităţii internaţionale, luând în considerare constatările făcute de cele două grupuri de lucru.

\section{Caracteristicile principiului suveranităţii statului}

Pentru a justifica ideea de suveranitate a statului în Cyberspace, se foloseşte principiul suveranităţii teritoriale. Deşi principiul a fost consacrat cu multă vreme în urmă, dreptul internaţional nu conţine o definiţie exhaustivă a acestuia, astfel încât identificarea elementelor şi semnificaţiei acesteia este relevantă pentru

https://undocs.org/en/A/RES/73/266, accesat 21.10.2021; United Nations General Assembly, Open-ended working group on developments in the field of information and telecommunications in the context of international security, Final Substantive Report, 10 March 2021, Final Substantive Report, A/AC.290/2021/CRP.2, [Online] la https://ict4peace.org/wp-content/uploads/2021/03/Final-report-A-AC.290-2021-CRP.2.pdf, accesat 21.10.2021.

${ }^{22}$ E. Tikk, M. Kerttunen, The Alleged Demise of the UN GGE: An Autopsy and Eulogy, in Cyber Policy Institute, 2017, p. 14.

${ }^{23}$ Statements by the Republic of Finland Open-Ended Working Group on Developments in the Field of Information and Telecommunications in the Context of International Security Virtual Informal Consultations 19 June and 2 July 2020, Statement 2 delivered 2 July 2020, [Online] la https://front.un-arm.org/wp-content/uploads/2020/09/oewginformal-virtual-meetings-statement-by-finland-19-june-and-2-july-2020.pdf, accesat 10.09.2021.

${ }^{24} \mathrm{OEWG}$, The future of discussions on ICTs and Cyberspace at the UN, [Online] la https://front.un-arm.org/wp-content/uploads/2020/10/joint-contribution-poa-the-futureof-cyber-discussions-at-the-un-10302020.pdf, accesat 10.10.2021. 
analiza aplicabilităţii acestuia în mediul analizat şi pentru identificarea limitelor sale, cum sunt jurisdicţia şi imunităţile statului. Complexitatea conceptului este amplificată de faptul că sensul modern al suveranităţii se referă la popoarele din cadrul statului, nu exclusiv la statul însuşi ca entitate juridică ${ }^{25}$.

Suveranitatea ca principiu datează din secolul al XVI-lea şi este unul dintre conceptele dezvoltate după Pacea de la Westfalia din $1648^{26}$. Sistemul Westfalian considera că statele deţin suveranitate asupra teritoriilor şi afacerilor interne ale acestora fără intervenţia altor state.

Principiul suveranităţii statului este unul dintre principiile fundamentale ale dreptului internaţional, consacrat în articolul 2 paragraful 1 din Carta Naţiunilor Unite $^{27}$ şi instrumentele juridice ulterioare (Declaraţia privind principiile dreptului internaţional, relaţiile de prietenie şi cooperarea între state în conformitate cu Carta Naţiunilor Unite 28 , Actul Final Helsinki ${ }^{29}$, Carta de la Paris pentru o nouă Europă $\breve{a}^{30}$ ) au menţionat, de asemenea, acest principiu şi valoarea sa ridicată pentru dreptul internaţional şi au stabilit legături între acesta şi alte principii fundamentale precum neintervenţia, autodeterminarea, integritatea teritorială şi soluţionarea paşnică a diferendelor ${ }^{31}$.

Dintr-o perspectivă teritorială, suveranitatea statului şi alte principii fundamentale ale dreptului internaţional se aplică tuturor componentelor teritoriului unui stat aflat în interiorul graniţelor sale (terestre, maritime, aeriene) în care acesta se bucură de o exclusivitate incontestabilă şi plenitudine de competenţă. Toate elementele suveranităţii statului se referă şi sunt analizate în legătură cu teritoriul fizic al statului în funcţie de stadiul de evoluţie al regulilor şi conceptelor de drept internaţional. Suveranitatea, atribut esenţial al statului atât la nivel internaţional cât şi intern ${ }^{32}$, descrie competenţele statelor şi prezintă de fapt sensuri

25 S. Besson, Sovereignty, International Law and Democracy, in The European Journal of International Law, Vol. 22 no. 2, 2011, p. 383, https://doi.org/10.1093/ejil/chr029.

${ }^{26}$ A. Osiander, Sovereignty, International Relations, and the Westphalian Myth, in International Organization, vol. 55, no. 2, 2001, pp. 251-287, DOI: https://doi.org/10.1162/ 00208180151140577.

${ }^{27}$ Articolul 2 paragraful 1 al cartei Naţiunilor Unite prevede: „1. Organizația este întemeiată pe principiul egalității suverane a tuturor Membrilor ei”.

28 United Nations General Assembly Resolution 2625 (XXV), adopted on 24 October 1970, A/RES/26/25 (XXV), Declaration on Principles of International Law concerning Friendly Relations and Cooperation among States in accordance with the Charter of the United Nations (24 October 1970).

${ }^{29}$ Organization for Security and Co-operation in Europe, Helsinki Final Act, August 1975, [Online] la https://www.osce.org/helsinki-final-act, accesat 12.10.2021.

30 Organization for Security and Co-operation in Europe, Charter of Paris for a New Europe, 21 November 1990, [Online] la https://www.osce.org/mc/39516, accesat 12.10.2021.

${ }^{31}$ H. Steinberger, "Sovereignty", în Encyclopedia of Public International Law, Volume four, North-Holland, Elsevier, 2000, p. 513.

32 J. Combacau, S. Sur, Droit international public, $12^{\mathrm{e}}$ edition, LGDJ 2016, p. 238; M. Bennouna, Le droit international entre la lettre et l'esprit. Cours général de droit international public, (Collected Courses of the Hague Academy of International Law, Tome 383, Brill /Nijhoff), 2016, p. 42. 
multiple, este indivizibilă, exclusivă, inalienabilă şi reprezintă o garanţie a derulării relaţiilor dintre state ${ }^{33}$, bazate pe independenţă şi lipsa de subordonare a unui stat faţă de celelalte ${ }^{34}$.

În analiza conţinutului şi a implicaţiilor principiului suveranităţii, multe lucrări academice au ca reper concluziile din cauza Insula Palmas ${ }^{35}$, ce a analizat dimensiunea teritorială a suveranităţii astfel:

„Suveranitatea teritorială (...), implică dreptul exclusiv al unui stat a-şi face publice activitățile. Acest drept are corolar o îndatorire: obligaţia de a proteja în interiorul teritoriului drepturile altor state, în special dreptul lor la integritate și inviolabilitate în timp de pace şi război, împreună cu drepturile pe care fiecare stat le poate pretinde pentru cetățenii săi pe teritoriul străin'36. În acelaşi timp, trebuie subliniat că hotărârea arbitrală a avut în vedere natura dinamică a conceptului de suveranitate, şi a menţionat:

„Manifestările de suveranitate teritorială îmbracă, este adevărat, forme diferite, in funcţie de condiţiile de timp şi de loc" ${ }^{\prime 3}$.

Această concluzie poate fi folosită pentru a justifica interpretarea restrictivă a suveranităţii statului în Cyberspace.

Suveranitatea se bazează pe ideea exercitării controlului sau a unei manifestări de autoritate pe un anumit teritoriu ${ }^{38}$ al statului şi a altor spaţii cu statut juridic special şi include controlul asupra tuturor persoanelor de pe teritoriu ${ }^{39}$, care are semnificaţiia exercitării competenţei (competenţă prescriptivă, competenţă de a judeca, competenţă de executare). Sensul principiului suveranităţii este rezultatul evoluţiei şi are o semnificaţie diferită de cea pe care a prezentat-o în secolele al XVI-lea şi al XVII-lea când a apărut ca urmare a intenţiei monarhiilor europene de a-şi consolida poziţia în raport cu biserica ${ }^{40}$.

Transpunerea în Cyberspace a ideii de suveranitate având conţinutul anterior descris, are ca efect exercitarea controlului în acest mediu asupra elementelor care susţin suveranitatea. În acest sens, lucrările grupurilor din cadrul Naţiunilor Unite - GGE şi OEWG nu se referă la o idee abstractă de suveranitate, ci se raportează la infrastructura IT \&C aparţinând statului sau situată pe teritoriul acestuia, abordare pe deplin compatibilă cu caracteristicile şi elementele suveranităţii.

${ }^{33}$ C. Moldovan, Drept internațional public. Principii și instituții fundamentale, Ediția a IIa, Editura Universul Juridic, București, 2019, p. 140.

${ }^{34} \mathrm{~J}$. Crawford, Brownlie's Principles of Public International Law, Eighth Edition, Oxford University Press, 2012, p. 447.

${ }^{35} \mathrm{PCA}$, Island of Palmas Case (or Miangas), United States of America v. The Netherlands, Award of the Tribunal, 4 April 1928, [Online] la https://pcacases.com/web/sendAttach/714, accesat 20.10.2021.

${ }^{36}$ Idem, p. 9.

${ }^{37}$ Ibidem.

${ }^{38}$ ICJ, Territorial and Maritime Dispute (Nicaragua v. Colombia) Judgment of 19 November 2012.

${ }^{39}$ A. Cassese, International Law, Second Edition, Oxford University Press, 2005, p. 49.

${ }^{40}$ M. Bennouna, op. cit., p. 41. 


\section{Divergenţe şi confluenţe asupra suveranităţii cibernetice}

Conceptul de suveranitate cibernetică a fost folosit pentru prima dată promovat intens de China şi include mai multe prerogative ale statului, conform legislaţiei naţionale, de a reglementa conduita persoanelor private în legătură cu folosirea internetului şi a datelor cu caracter personal pe teritoriul său, ca mijloc de protejare a spaţiului informaţ̧ional, în conformitate cu politica generală privind controlul internetului şi fluxul de date ${ }^{41}$. Statul chinez a iniţiat proiectul numit The Golden Shield, în 1996 şi l-a implementat în $2008^{42}$. Acesta este exemplul perfect, deoarece stabileşte controlul deplin al statului asupra informaţiilor şi accesului la informaţii.

Acelaşi tip de abordare este reflectată şi extinsă de legislaţia internă a Federaţiei Ruse care a adoptat în 2019 „Legea suverană a internetului” ${ }^{\text {”3 }}$ ce stabileşte cadrul legal pentru controlul asupra internetului între frontierele acesteia ${ }^{44}$. Federaţia Rusă a susţinut crearea unei reţele naţionale proprii pentru care a fost deja făcute teste şi utilizatorii nu au întâmpinat probleme sau nici măcar nu şi-au dat seama că au intervenit schimbări. Anterior, în decembrie 2016, Preşedintele Federaţiei Ruse a aprobat doctrina securităţii informaţ̧ionale care presupune crearea internetului şi mediului cibernetic naţional, precum şi separarea acestuia de spaţiul cibernetic internaţional ${ }^{45}$.

Justificarea dată de preşedintele rus este că aceasta reprezintă o măsură de securitate pentru protejarea statului în cazul unei „urgenţe sau ameninţări străine precum un atac cibernetic" ${ }^{36}$. Potrivit legii, statul are prerogativa de a controla internetul prin infrastructura instituită în Rusia şi de a crea un sistem propriu de nume pentru domeniile de internet. Din perspectiva consecinţelor sale, o astfel de măsură constituie deconectarea reţelei de infrastructură rusă de la reţeaua globală şi în mod practic, constituie instaurarea cenzurii pentru utilizatorii săi.

O astfel de posibilitate tehnică poate fi pusă în practică fără mare dificultate şi ar putea fi văzută ca o manifestare a jurisdicţiei teritoriale ${ }^{47}$. Totuşi, situaţia în care toate statele, în numele suveranităţii cibernetice, şi-ar crea şi izola reţeaua

${ }^{41}$ D. Broeders, L. Adamson, R. Creemers, op. cit., p. 2.

${ }^{42}$ S. Chandel, Z. Jingji, Y. Yunnan, S. Jingyao, Z. Zhipeng, The Golden Shield Project of China: A Decade Later-An in-Depth Study of the Great Firewall, în 2019 International Conference on Cyber-Enabled Distributed Computing and Knowledge Discovery (CyberC), 2019, p. 111-119, DOI: https://doi.org/10.1109/CyberC.2019.00027.

${ }^{43}$ A. Epifanova, Deciphering Russia's "Sovereign Internet Law" Tightening Control and Accelerating the Splinternet, German Council on Foreign Relations DGAP Analysis, No 2 January 2020, [Online] la https://dgap.org/sites/default/files/article_pdfs/dgap-analyse_22020_epifanova_0.pdf, accesat 12.10.2021.

${ }^{44}$ Ibidem.

45 [Online] la https://www.cnbc.com/2019/11/01/russia-controversial-sovereigninternet-law-goes-into-force.html, accesat 10.11.2021.

46 [Online] la https://www.cnbc.com/2019/11/01/russia-controversial-sovereigninternet-law-goes-into-force.html, accesat 10.11.2021.

${ }^{47}$ W.H. Heintschel von Heinegg, op. cit., p. 9. 
naţională, nu ar mai corespunde ideii de reţea internaţională globală aşa cum o cunoaştem şi o folosim astăzi şi ar sacrifica cu siguranţă internetul ${ }^{48}$. Ar fi doar o extindere a teritoriului naţional, controlat în întregime de stat, inclusiv controlul asupra datelor, fluxului de date, utilizatorilor, parametrilor tehnici şi caracteristicile generale ale acestui spaţiu.

La polul opus, o abordare diferită, mult mai temperată calitativ şi cantitativ aparţine Franței şi a fost exprimată în Cartea Albă a Apărării şi Securităţii Naţionale din $2013^{49}$, care se concentrează asupra necesităţii de a proteja integritatea statului şi a infrastructurii în anumite cazuri care ar echivala cu un atac armat. Această viziune a fost extinsă în acte ulterioare precum Strategia internaţională din $2017^{50}$ şi Analiza strategică din 2018 a apărării cibernetice ${ }^{51}$. Aceasta din urmă afirmă că:

„(...) principiul suveranităţii se aplică spaţiului cibernetic. În acest sens, Franţa îşi reafirmă suveranitatea asupra infrastructurii tehnologiilor informaţiei şi comunicațiilor, a persoanelor şi a activităţilor cibernetice situate pe teritoriul său, sub rezerva obligațiilor sale legale internaţionale".

Franţa a dezvoltat un sistem naţional de definire şi calificare a acţiunilor care constituie un incident de securitate cibernetică. În stabilirea pragului unei încălcări de suveranitate, abordarea franceză se concentrează pe comportamentul în sine reprezentând pătrunderea sistemului IT\&C, nu pe consecinţele produse.

Un alt exemplu de abordare globală asupra Cyberspace este reprezentat de Statele Unite ale Americii, care propune Strategia naţională cibernetică din $2018^{52}$, axată pe ideea de mediu global şi deschis ce promovează:

„un cadru pentru comportamentul responsabil al statului în Cyberspace construit pe dreptul internaţional, aderarea la normele voluntare neobligatorii de comportament responsabil al statului, care se aplică în timp de pace şi luarea in considerare a măsurilor practice de consolidare a încrederii pentru a reduce

${ }^{48}$ M. Mueller, op. cit., p. 5.

${ }^{49}$ Direction générale des relations internationales et de la stratégie (DGRIS)/Directorate General for International Relations and Strategy, White Paper on Defence and National Security 2013, [Online] la https:/www.defense.gouv.fr/english/dgris/defence-policy/whitepaper-2013/white-paper-2013, accesat 20.11.2021.

${ }^{50}$ French Foreign Policy, Stratégie internationale de la France pour le numérique, [Online] la https:/www.diplomatie.gouv.fr/en/french-foreign-policy/digital-diplomacy/france-sinternational-digital-strategy/https:/www.ife.ee/en/international-strategy-for-digital/, accesat 20.11.2021.

${ }^{51}$ Secretary general on Defense and National Security (France), Strategic review of cyber defence, February 2018, [Online] la http://www.sgdsn.gouv.fr/uploads/2018/03/revuecyber-resume-in-english.pdf, accesat 20.11.2021; F. Delerue, A. Géry, France's Cyberdefense Strategic Review and International Law, March 23, 2018, [Online] la https://www.lawfareblog.com/frances-cyberdefense-strategic-review-and-internationallaw, accesat 20.11.2021.

${ }^{52}$ The White House, National Cyber Strategy of the United States of America, September 2018, p. 20, [Online] la https://trumpwhitehouse.archives.gov/wp-content/uploads/ 2018/09/National-Cyber-Strategy.pdf, accesat 20.11.2021. 
riscul de conflict care decurge din activitatea cibernetică rău intenționată. Aceste principii ar trebui să formeze o bază pentru cooperarea statelor în scopul contracarării acțiunilor care nu sunt conforme cu acest cadru."

În 2021, a fost emis un Ordin executiv pentru îmbunătăţirea securităţii cibernetice naţionale, care se axează pe adoptarea de măsuri pentru protejarea mediului cibernetic, supus unor numeroase atacuri ${ }^{53}$.

Regatul Unit a dezvoltat de asemenea, o strategie naţională de securitate cibernetică ${ }^{54}$, a creat un centru naţional pentru securitate cibernetică ${ }^{55}$ şi susţine aplicabilitatea suveranităţii ca principiu, considerând că nu există o regulă a suveranităţii în Cyberspace ${ }^{56}$. Din punct de vedere teoretic şi practic, diferenţele dintre cele două abordări ale suveranităţii: ca principiu şi ca regulă, nu sunt de fapt foarte clare şi eficacitatea lor poate să nu fie semnificativă, deoarece în fiecare caz există obligaţii internaţionale pentru state.

Poziţiile exprimate public de state cu privire la suveranitatea în Cyberspace pot fi foarte diferite în practică, ceea ce face dificilă argumentarea existenţei unei opinio iuris asupra modului în care aceasta se aplică, însă această situaţie nu înseamnă în mod necesar existenţa unui vid normativ ${ }^{57}$.

$\mathrm{Nu}$ toate statele au exprimat puncte de vedere detaliate ${ }^{58} \mathrm{cu}$ privire la modalitatea în care dreptul internaţional se aplică în Cyberspace, însă tăcerea statelor sau poziţia lor ambiguă poate fi cea mai bună modalitate de a asigura aplicarea dreptului internaţional în spaţiul cibernetic.

\section{Concluzii}

Noţiunea de „suveranitate digitală” este una ambiguă, în ciuda eforturilor de a clarifica implicaţiile acesteia în Cyberspace făcute la nivelul Naţiunilor Unite. Sunt

53 The White House, Executive Order On Improving the Nations `s Cybersecurity, May 12, 2021, [Online] la https://www.whitehouse.gov/briefing-room/presidential-actions/ 2021/05/12/executive-order-on-improving-the-nations-cybersecurity/, accesat 20.11.2021.

${ }^{54}$ Cabinet Office and National Security and Intelligence, National Cyber Security Strategy 2016 to 2021: progress so far, [Online] la https://www.gov.uk/ government/ publications/national-cyber-security-strategy-2016-to-2021-progress-so-far, accesat 20.11.2021.

${ }^{55}$ National Cyber Security Centre, [Online] la https://www.ncsc.gov.uk/section/aboutncsc/what-we-do, accesat 20.11.2021.

${ }^{56}$ UK Attorney General Jeremy Wright Speech, Cyber and International Law in the 21st Century, 23 May 2018, [Online] la https://www.gov.uk/government/speeches/cyber-andinternational-law-in-the-21st-century, accesat 21.11.2021.

${ }^{57} \mathrm{M}$. Tolppa Overview of the UN OEWG developments: continuation of discussions on how International Lawapplies in cyberspace, 2020, [Online] la https://ccdcoe.org/ library/publications/overview-of-un-oewg-developments-continuation-of-discussions-onhow-international-law-applies-in-cyberspace/, accesat 21.11.2021.

${ }^{58} \mathrm{O}$ prezentare a pozițiilor statelor în cadrul sesiunilor OEWG poate fi consultată [Online] la https://www.un.org/disarmament/open-ended-working-group/, accesat 20.11.2021. 
necesare eforturi suplimentare din partea statelor şi a organismelor internaţionale pentru a defini această noţiune şi a stabili conţinutul şi limitele sale, prin referire la principiul fundamental al suveranităţii statului.

Faptul că grupurile de lucru special create în cadrul Naţiunilor Unite nu au reuşit să dezvolte norme de drept internaţional prin mijloace şi canale diplomatice subliniază această necesitate. Deşi activitatea şi constatările sale au fost incomplete şi uneori criticate, Naţiunile Unite rămâne cel mai potrivit şi legitim forum deschis tuturor statelor pentru a discuta toate tipurile de probleme legate de acest mediu, iar dezbaterile din Adunarea Generală pot oferi premisele opinio juris asupra comportamentului statelor şi a unei guvernări globale în Cyberspace.

Conceptul de „suveranitate cibernetică” se opune ideii de guvernanţă globală şi nu ţine cont de interesele tuturor părţilor interesate (mutistakeholders), cum ar fi companiile private şi persoanele private. Exercitarea suveranităţii statului în acest mediu este limitată şi nu are aceeaşi sferă ca şi teritoriul fizic al statului. $\mathrm{O}$ abordare echilibrată în această privinţă ar fi luarea în considerare a unei semnificaţii diferite, raportat la elementele infrastructurii fizice de care depinde existenţa Cyberspace, urmând a fi clarificate noţiuni precum jurisdicţia statului, efectele extrateritoriale ori încălcarea suveranităţii în spaţiul virtual.

\section{Referinţe}

Arsène S., Global Internet Governance in Chinese Academic Literature. Rebalancing a Hegemonic World Order? in China Perspectives 2016/2 | 2016 What Kind of International Order Does China Want, p. 28, https://doi.org/10.4000/chinaperspectives.6973

Baezner M., Robin P., Trend Analysis: Cyber Sovereignty, Risk and Resilience Team Center for Security Studies (CSS) ETH Zürich, 2018

Bennouna M., Le droit international entre la lettre et l'esprit. Cours général de droit international public, (Collected Courses of the Hague Academy of International Law, Tome 383, Brill /Nijhoff), 2016

Besson S., Sovereignty, International Law and Democracy, in The European Journal of International Law Vol. 22 no. 2, 2011, https://doi.org/10.1093/ejil/chr029.

Broeders D., Adamson L., Creemers R., Coalition of the unwilling? Chinese and Russian perspectives on cyberspace, in The Hague Program For Cyber Norms Policy Brief, November 2019

Cabinet Office and National Security and Intelligence, National Cyber Security Strategy 2016 to 2021: progress so far, 2021

Cassese A., International Law, Second Edition, Oxford University Press, 2005

Chandel S., Jingji Z., Yunnan Y., Jingyao S., Zhipeng Z., The Golden Shield Project of China: A Decade Later-An in-Depth Study of the Great Firewall, în 2019 International Conference on Cyber-Enabled Distributed Computing and Knowledge Discovery (CyberC), 2019, https://doi.org/10.1109/CyberC.2019.00027

Combacau J., Sur S., Droit international public, $12^{\mathrm{e}}$ edition, LGDJ, 2016

Council of Europe, Convention on Cybercrime, 23.XI.2001, ETS No.185

Crawford J., Brownlie's Principles of Public International Law, Eighth Edition, Oxford University Press, 2012

Delerue F., Géry A., France's Cyberdefense Strategic Review and International Law, March 23, 2018 
Direction générale des relations internationales et de la stratégie (DGRIS)/Directorate General for International Relations and Strategy, White Paper on Defence and National Security, 2013

Donahoe E., The Need for a Paradigm Shift on Digital Security, eds. Fen Osler Hampson and Michael Sulmeyer, Getting beyond Norms New Approaches to International Cyber Security Challenges Special Report, Centre for International Governance Innovation, 2017

Epifanova A., Deciphering Russia's „Sovereign Internet Law” Tightening Control and Accelerating the Splinternet, German Council on Foreign Relations DGAP Analysis, no $2 / 2020$

Heintschel von Heinegg W., Legal Implications of Territorial Sovereignty in Cyberspace, in 4th International Conference on Cyber Conflict C. Czosseck, R. Ottis, K. Ziolkowski (Eds.), NATO CCDCOE Publications, 2012

Moldovan C., Drept internaţional public. Principii şi instituţii fundamentale, Ediţia a II-a, Editura Universul Juridic, Bucureşti, 2019

Moldovan C., Blurred lines in defining the conduct of States in Cyberspace. A critical analysis on the cyber sovereignty and impact over free access to information, presented at European Society of International Law Kraków-Leiden Online Symposium on 'Exploring the Frontiers of International Law in Cyberspace', 4 December 2020

Moldovan C., Limits of International Law in a limitless Cyberspace. Challenges and uncertainties, în Analele Ştiinţifice ale Universităţii „Alexandru Ioan Cuza” din Iaşi, Tomul LXVI/Supliment, Ştiinţe juridice, 2020

Moldovan C., Are there any limits to the rights of States in Cyberspace? An analysis from the perspective of International Law, presented at the 13th Biennial International Conference organised by the Faculty of Law of the West University of Timişoara, 6-7 November 2020

Moynihan H., Power Politics Could Impede Progress on Responsible Regulation of Cyberspace, December $3^{\text {rd }} 2019$

Mueller M., Sovereignty and Cyberspace: Institutions and Internet governance, Essay presented at the 5th Annual Vincent and Elinor Ostrom Memorial Lecture, given at the University of Indiana October $3^{\text {rd }} 2018$

Nyman Metcalf K., Legal View on Outer Space and Cyberspace: Similarities and Difference, Tallinn Paper, no. 10/2018

Ottis R., Lorents P., Cyberspace: Definition and Implications, in Proceedings of the $5^{\text {th }}$ International Conference on Information Warfare and Security, Dayton, OH, US, 8-9 April 2010

OEWG, The future of discussions on ICTs and Cyberspace at the UN, on-line.

Organization for Security and Co-operation in Europe, Helsinki Final Act, August 1975, online

Osiander A., Sovereignty, International Relations, and the Westphalian Myth, in International Organization, vol. 55, no. 2, 2001, DOI: https://doi.org/10.1162/00208180151140577

PCA, Island of Palmas Case (or Miangas), United States of America v. The Netherlands, Award of the Tribunal, 4 April 1928

Shen Y., Cyber Sovereignty and the Governance of Global Cyberspace, Chin. Polit. Sci. Rev. 1/2016, pp. 81-93

Steinberger H., "Sovereignty", în Encyclopedia of Public International Law (Volume four, North-Holland, Elsevier, 2000

Tikk E., Kerttunen M., The Alleged Demise of the UN GGE: An Autopsy and Eulogy, in Cyber Policy Institute, 2017 
Tolppa M., Overview of the UN OEWG developments: continuation of discussions on how International Law applies in cyberspace, 2020, on-line

United Nations General Assembly, Group of Governmental Experts on Developments in the Field of Information and Telecommunications in the Context of International Security, para. 19, U.N. Doc. A/68/98, June $24^{\text {th }}, 2013$

United Nations General Assembly, Report of the Group of Governmental Experts on Developments in the Field of Information and Telecommunications in the Context of International Security, A/70/174, 2015

United Nations General Assembly,"Resolution adopted by the General Assembly on 22 December 2018 on „Advancing responsible State behaviour in Cyberspace in the context of international security”, UN Doc A/RES/73/266, 2018

United Nations General Assembly, Open-ended working group on developments in the field of information and telecommunications in the context of international security, Final Substantive Report, Final Substantive Report, A/AC.290/2021/CRP, 2021

United Nations General Assembly Resolution 2625 (XXV), adopted on 24 October 1970, A/RES/26/25 (XXV), Declaration on Principles of International Law concerning Friendly Relations and Cooperation among States in accordance with the Charter of the United Nations, 1970

UNODA, Fact Sheet - Developments in the field of information and telecommunications in the context of International Security, 2019, on-line

The White House, National Cyber Strategy of the United States of America, September 2018

The White House, Executive Order On Improving the Nations`s Cybersecurity, May 12, 2021, on-line

UK Attorney General Jeremy Wright Speech, Cyber and International Law in the $21^{\text {st }}$

Century, 23 May 2018

Zeng J., Stevens T., Chen Y., China's Solution to Global Cyber Governance: Unpacking the Domestic Discourse of 'Internet Sovereignty', Politics \& Policy, Volume 45, no. 3/2017, https://doi.org/10.1111/polp.12202. 